\title{
USE OF ARTIFICIAL BASKING SUBSTRATE TO DETECT AND MONITOR PACIFIC POND TURTLES (EMYS MARMORATA)
}

\author{
Jeff A. Alvarez ${ }^{1}$
}

Key words: artificial, basking, construction, emydid, monitor, platform, turtle.

Many species of turtles, lizards, snakes, and crocodilians are known to bask diurnally. Cagle (1950) suggested that emydid turtles bask to thermoregulate, to condition the skin or shell, and to retard epizootic and epiphytic infestations. However, Boyer (1965) determined, through field and laboratory study, that the basking response in turtles is driven primarily by the need to thermoregulate. Many semiaquatic turtles are known to bask on rocks, logs, vegetation mats, and floating debris (Cagle 1950, Boyer 1965, Bury and Wolfheim 1973, Lindeman 1999). Petokas and Alexander (1979) developed a trap that utilized the basking behavior in semiaquatic turtles to facilitate trapping them. Bury and Wolfheim (1973) reported on the aggressive interactions of basking Pacific pond turtles (Emys marmorata).

Because Pacific pond turtles are declining in California, it has become increasingly important to detect them within their habitat (Jennings and Hayes 1994). The purpose of this study was to demonstrate that an artificial basking substrate (basking platform) could be easily constructed and deployed, and with this technique the presence of aquatic turtles could be detected and monitored within simple and complex aquatic habitats.

The Los Vaqueros Watershed (hereafter watershed), which is part of the upper Kellogg Creek drainage, is located ca. $57 \mathrm{~km}$ east of San Francisco, California. Habitat consists primarily of annual and perennial grasslands, oak (Quercus spp.) woodlands, riparian woodlands, perennial drainages, ephemeral and seasonal wetlands, chaparral, open water, and rock outcrops. Los Vaqueros Reservoir, Kellogg Creek and its tributaries, and 40 perennial stock ponds provide suitable habitat for aquatic turtles. Fifty additional ephemeral stock ponds and wetlands provide refuge for dispersing turtles.

Fourteen rectangular basking platforms were constructed in 2 different designs (Fig. 1). One type was made primarily of wood with added floatation $(n=8)$. The 2 nd design was constructed using a foam panel and also included additional floatation, but to a lesser extent $(n$ $=6$ ). Platforms were floated at an oblique angle to the water surface by attaching 1 or more $60-\mathrm{cm}$ capped polyvinyl chloride tubes (Fig. 1).

Baseline surveys for southwestern pond turthes (E. m. pallida) were conducted throughout the watershed in 1998, prior to the placement of basking platforms. Biologists surveyed ponds and creeks on foot by using binoculars to initially scan the water surface and shoreline from a distance. They also walked along the perimeter of ponds and creeks and noted where southwestern pond turtles were observed.

In early spring 1999 my assistant and I placed basking platforms in 9 ponds and 2 creeks where aquatic emydid turtles were known to occur historically, or where habitat appeared suitable but where no turtles had previously been found. We placed platforms in open water, and each platform was anchored to the bottom with a length of nylon cord and a concrete weight. Turtles were given $2-7$ days to acclimate to the new structures.

Surveys for turtles were made 5-6 times per year for up to 5 years beginning several days after basking platforms had been deployed. Additional observations of turtles using basking platforms were recorded coincident with mitigation monitoring surveys for California

${ }^{1}$ The Wildlife Project, Box 579805, Modesto, CA 95357. 


\section{Design A}

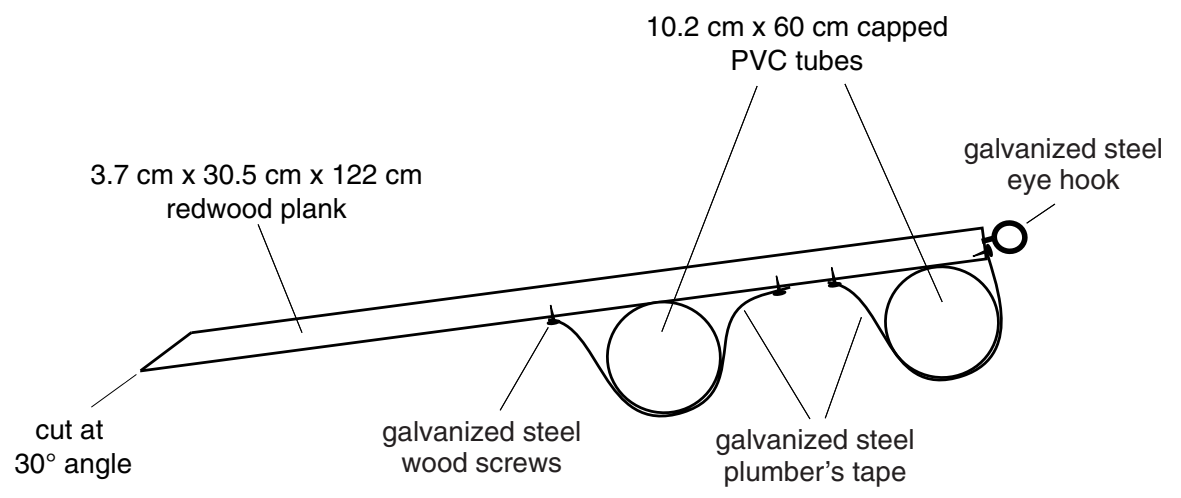

\section{Design B}

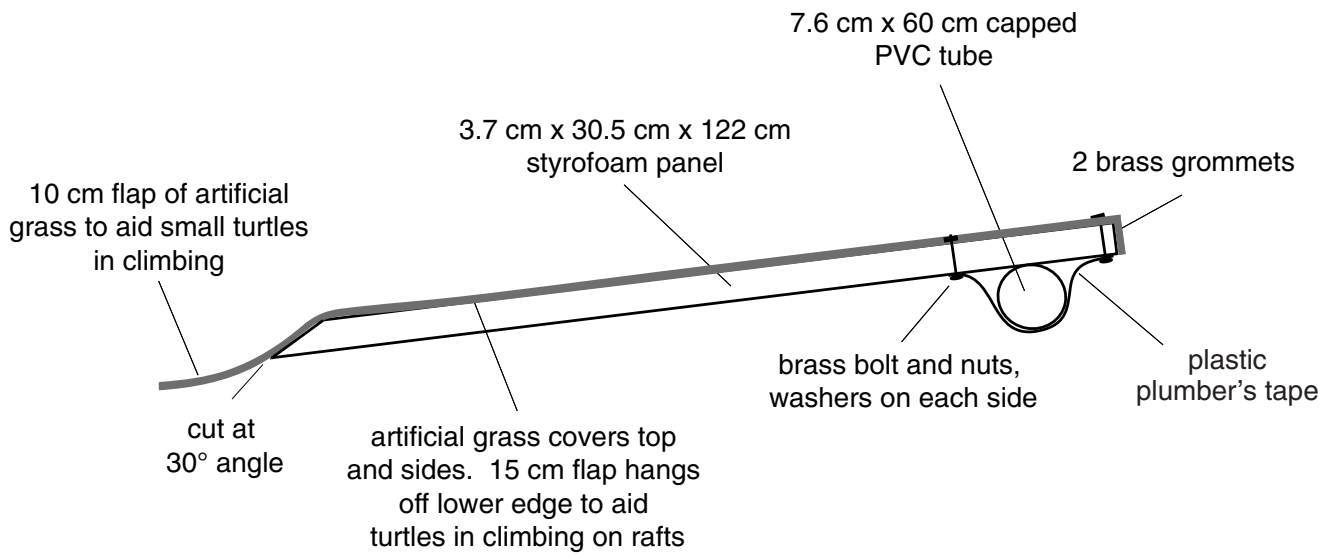

Fig. 1. Design and floating position of 2 styles of basking platform used to detect and monitor Pacific pond turtles at the Los Vaqueros Watershed, east Contra Costa County, California. Design B was constructed from a foam panel that was covered by artificial grass (e.g., AstroTurf ${ }^{\circledR}$ ). Artificial grass is glued to the top and 4 sides, and is folded over and glued along the bottom edge of the foam panel.

red-legged frogs (Rana draytonii) in ponds and creeks in the watershed.

Baseline surveys in 1998 indicated southwestern pond turtles occupied 2 ponds and 2 creeks in the watershed. A maximum of 11 southwestern pond turtles were observed basking on the bank of 1 of the 2 ponds; 2 southwestern pond turtles were detected in the 2 nd pond. Although southwestern pond turtles were observed in the 2 creeks, no attempt was made to determine their numbers.
Within 2-7 days after deployment of the basking platforms, southwestern pond turtles were detected in 8 of the 9 ponds and in both creeks. The maximum number of turtles detected in ponds was 49 (34 turtles in a single pond). Moreover, southwestern pond turtles were detected in 6 ponds where they were not previously known.

Within occupied habitat, observations of basking emydid turtles are relatively common when appropriate basking substrate is present 
(Bury and Wolfheim 1973, Reese and Welsh 1998; personal observation). However, complex aquatic habitats (i.e., ponds or creeks with dense emergent or riparian vegetation) may reduce or eliminate the ability of an observer to detect turtles. Prior to this study, emergent vegetation in 5 of the 9 ponds where basking platforms were deployed was so dense that those ponds were considered impractical to survey and no southwestern pond turtles were believed to occur. However, after basking platforms were deployed, 3-11 southwestern pond turtles were observed in each of those 8 ponds with a highly complex habitat.

Northwestern pond turtles (E. m. marmorata) could be detected in lakes and ponds in the state of Washington by supplying the turtles with basking substrate (Nordby unpublished report, Stringer unpublished report). In this study, detection and observations of southwestern pond turtles increased dramatically through the use of basking platforms. Observational studies and surveys of basking southwestern pond turtles at the Los Vaqueros Watershed were performed more efficiently after deployment of basking platforms. Timing and temperature relationships of basking (Alvarez unpublished report) and length of basking time among different age classes (Wilkerson unpublished report) were both studied using the basking platforms. Further, ongoing monitoring of the presence, distribution, and abundance of this population of southwestern pond turtles is being conducted at the Los Vaqueros Watershed using the basking platforms described in this study. These platforms were also deployed in Los Vaqueros Reservoir as a means to attract and monitor nonnative species of emydid turtle that may be introduced into the watershed. Species using basking platforms within the reservoir were identified using a spotting scope, and trapping was used to remove nonnative species within areas where they were detected.

The basking platform designs described above have proven durable; platforms have lasted up to 6 years in the field. The designs offered here are inexpensive and easily transportable. Costs for materials used to construct basking platforms ranged from $\$ 9.00$ to $\$ 19.00$ depending upon the style selected. This technique can be used as part of a short-term presence-absence survey by deploying basking platforms at least 7 days before a survey and returning to observe animals that may be basking during the day. Behavioral studies of basking turtles can also be facilitated through the use of this technique.

I thank M.A. Shea for field assistance in setting up platforms and observing turtles, and for comments on the manuscript. I also thank J.L. Alvarez for constructive discussions and helpful comments on the manuscript. Valuable editorial comments were received from R.W. Baumann and 2 anonymous reviewers. The Contra Costa Water District provided access to the habitats within the Los Vaqueros Watershed for which I am grateful.

\section{Literature Cited}

BOyER, D.R. 1965. Ecology of the basking habit in turtles. Ecology 46:99-118.

Bury, R.B., AND J.H. Wolfheim. 1973. Aggression in freeliving pond turtles (Clemmys marmorata). BioScience 23:659-662.

Cagle, F.R. 1950. The life history of the slider turtle, Pseudemys scripta trootsii (Holbrook). Ecological Monographs 20:31-54.

Jennings, M.R., And M.P. Hayes. 1994. Amphibian and reptile species of special concern in California. Report prepared for the California Department of Fish and Game, Inland Fisheries Division, Rancho Cordova, CA. $255 \mathrm{pp}$.

Lindeman, P.V. 1999. Aggressive interactions during basking among 4 species of emydid turtles. Journal of Herpetology 33:214-219.

Petokas, P.J., And M.M. Alexander. 1979. A new trap for basking turtles. Herpetological Review 10:90.

Reese, D.A., AND H.H. Welsh. 1998. Habitat use by western pond turtles in the Trinity River, California. Journal of Wildlife Management 62:843-853.

Received 26 July 2004 Accepted 30 March 2005 